Hurlock, B. \& Tosic, J. (1951). J. gen. Microbiol. 5, 587-591.

\title{
An Organism Able to Metabolize 3-Methylglucose and 3-Methylfructose
}

\author{
BY BARBARA HURLOCK AND J. TOSIC \\ Medical Research Council Unit for Chemical Microbiology, \\ Biochemical Laboratory, University of Cambridge
}

SUMMARY: An organism was isolated from soil, which grew in a basal mineral medium with either 3-methylglucose or 3-methylfructose as sole source of carbon. The bacterium is a member of the coli-aerogenes group, intermediate type 1. Grown in presence of either methyl-sugar, under suitable conditions, washed suspensions of the organism oxidize either 3-methylglucose or 3-methylfructose. Under anaerobic conditions, the two methyl-sugars are broken down with the formation of hydrogen, carbon dioxide and acid. The ability to attack 3-methylglucose or 3-methylfructose was acquired by growth in presence of either of the two methyl-sugars but not in the presence of glucose.

When 3-methylglucose is fed or administered to rats it is largely excreted in the urine unchanged (Campbell, 1949). The present investigation was undertaken in an attempt to discover whether micro-organisms exist which are able to attack and utilize both 3-methylglucose and 3-methylfructose, and whose existence might affect the use of these sugars in feeding experiments.

\section{METHODS}

Growth media. A basal mineral medium was prepared as follows: $\left(\mathrm{NH}_{4}\right)_{2}$ $\mathrm{HPO}_{4} .2 \mathrm{H}_{2} \mathrm{O}, 4.0 \mathrm{~g}$; $\mathrm{KH}_{2} \mathrm{PO}_{4}, 0.4 \mathrm{~g}$.; $\mathrm{NaCl}, 1.0 \mathrm{~g}$.; $\mathrm{MgSO}_{4} .7 \mathrm{H}_{2} \mathrm{O}, 0.7 \mathrm{~g}$; $\mathrm{FeSO}_{4} \cdot 7 \mathrm{H}_{2} \mathrm{O}, 0 \cdot 3 \mathrm{~g}$; distilled water to $1.0 \mathrm{l}$.; $\mathrm{pH}$ adjusted to $7 \cdot 0$. The basal medium was distributed in $9 \mathrm{ml}$. portions in miniature Roux bottles and sterilized by autoclaving $\left(110^{\circ}\right)$. Solutions $(10 \%, w / v)$ of 3-methylglucose or 3-methylfructose were sterilized by filtration through Seitz filters. One ml. of one or other of these solutions was added to each Roux bottle; for anaerobic growth the medium was distributed in flasks.

Preparation of washed suspensions of bacteria. After $36 \mathrm{hr}$. incubation at $30^{\circ}$ cultures were centrifuged; the cells were washed once in distilled water and made up into a suspension in water. The dry weight of cells in such suspensions was determined on the Hilger Spekker absorptiometer previously calibrated by dry-weight determinations.

Respiration experiments. Oxygen consumption was measured in Warburg manometers containing washed cell suspension, phosphate buffer $(\mathrm{pH} \mathrm{7 \cdot 0})$ and 3-methylglucose or 3-methylfructose; $\mathrm{NaOH}$ solution and filter-papers were placed into the centre cups to absorb $\mathrm{CO}_{2}$. The production of $\mathrm{CO}_{2}$ was determined in parallel experiments by omitting $\mathrm{NaOH}$ from the centre cup and releasing retained $\mathrm{CO}_{2}$ at the end of the experiment by tipping $\mathrm{H}_{2} \mathrm{SO}_{4}$ from a second side-bulb. Rates of oxidation are expressed as $\boldsymbol{Q}_{\mathrm{o}_{2}}$.

Fermentation experiments. The anaerobic breakdown of the methyl-sugars was studied in Warburg manometers. Gas production was measured in mano- 
meters filled as above but containing nitrogen gas; $\mathrm{CO}_{2}$ retained was measured by the acid-tip method as above; manometers were set up in duplicate, one of each pair containing $\mathrm{NaOH}$ in the centre cup to absorb $\mathrm{CO}_{2}$ if produced. Acid and gas production were measured in manometers containing washed suspension, $\mathrm{NaHCO}_{3}$ and 3-methylglucose or 3-methylfructose; the manometers were filled with a gas mixture containing $95 \%(\mathrm{v} / \mathrm{v}) \mathrm{N}_{2}$ and $5 \% \mathrm{CO}_{2}$. Acid production was calculated from the decrease in $\mathrm{NaHCO}_{3}$ concentration determined after the experiment by the usual acid-tip method. Gas production in the bicarbonate buffer system is expressed in terms of $\mathrm{CO}_{2}$.

\section{Isolation of organism utilizing methyl-sugars}

Several bottles each of the two media containing the respective methylsugars were inoculated with garden soil and aerobically incubated at $25^{\circ}$. In all cases the medium became turbid within 24-48 hr. During the first series of experiments, four serial subcultures were made into fresh medium at $48 \mathrm{hr}$. intervals. In a second series of experiments, four subcultivations were made at $24 \mathrm{hr}$. intervals. At the end of these periods the cultures were plated on the two media solidified with $3 \%$ of agar.

No consistent growth was obtained in the experiments using 3-methylglucose, the fourth subcultivation giving a slight amount of growth which proved to consist of a mixture of many different organisms. These experiments were discontinued, since an organism utilizing 3-methylglucose was isolated from the cultures containing 3-methylfructose.

The cultures grown with 3-methylfructose grew heavily and proved to consist of a mixture of four or five morphologically distinct organisms. In the culture series which had been subcultivated at $48 \mathrm{hr}$. intervals the predominant organism was isolated in pure culture and identified as a species of Pseudomonas. This organism, however, proved unable to grow in liquid medium with 3-methylfructose as sole source of carbon. This $P$ seudomonas species was not predominant on plates of cultures subcultivated at $24 \mathrm{hr}$. intervals, and four different colonies were selected from the plating of this series for further investigation. Organisms from these colonies were grown in 3-methylfructose media and then replated until pure cultures were obtained. At the same time the organisms were inoculated into Roux bottles containing $150 \mathrm{ml}$. 3-methylfructose medium, incubated at $30^{\circ}$ for $36 \mathrm{hr}$., harvested on the centrifuge, washed once in distilled water, resuspended in water and tested for ability to oxidize 3-methylfructose. Growth was poor with one strain (not further studied) but heavy with one and moderate with the remaining two. The respiration experiments indicated that the three organisms oxidized 3-methylfructose at different rates. The organism which gave heavy growth in $36 \mathrm{hr}$. at $30^{\circ}$ had $Q_{\mathrm{O}_{2}}$ (3-methylfructose) $=12-24$ in preliminary experiments; this organism was used for the studies reported in this paper.

\section{Identification of organism}

The organism was identified as Bacterium coli intermediate type 1 (Wilson, Twigg, Wright, Hendry, Cowell \& Maier, 1935). The bacterium has the morphological and cultural characteristics of Bact. coli intermediate type 1, 
with an optimal growth temperature range of $25-30^{\circ}$. This organism belongs to the type which is one of the commonest of all coliform bacteria found in soils of this country (Bardsley, 1934). The species with closest resemblance to our organism listed in Bergey's Manual (1948) is Escherichia freundii (Braak) Yale.

The biochemical characteristics of our strain can be summarized as follows: acid and gas formation, under aerobic conditions, took place in peptone broth after $18 \mathrm{hr}$. with arabinose, glucose (also at $37^{\circ}$ ), 3-methylglucose, fructose, 3-methylfructose, galactose, mannitol, sucrose, maltose and cellobiose. Acid and traces of gas after 3 days with rhamnose and lactose; acid but no gas with glycerol after $40 \mathrm{hr}$; neither acid nor gas from dulcitol, raffinose, inulin or starch. Under anaerobic conditions $\left(\mathrm{N}_{2} / \mathrm{CO}_{2}\right.$ or $\left.\mathrm{H}_{2} / \mathrm{CO}_{2}\right)$ acid and gas in peptone broth or Stephenson's medium with glucose, fructose, 3-methylglucose or 3-methylfructose (Stephenson, 1949).

Other biochemical reactions : nitrite formed from nitrate but no $\mathrm{N}_{2}$ liberated; hydrogen sulphide positive; indole negative; methyl-red positive; VogesProskauer negative; citrate utilization positive; urease negative; catalase positive; gelatine liquefaction negative after 14 days' incubation.

\section{Metabolism of 3-methylfructose and 3-methylglucose}

The growth tests indicated that the organism could utilize either 3-methylfructose or 3-methylglucose for aerobic or anaerobic growth. The organism was therefore grown on a larger scale for metabolic investigations in the defined basal medium containing the appropriate methyl-sugar. The ability of washed suspensions to oxidize the methyl-sugars was first tested and experiments were

\section{Table 1(a). Metabolism of 3-methylfructose by washed suspensions of cells grown in the presence of 3-methylfructose}

(Organism grown for $36 \mathrm{hr}$. at $30^{\circ}$ in basal medium $+0.5 \%(\mathrm{w} / \mathrm{v})$ 3-methylfructose. Suspension density: $22 \mathrm{mg}$. dry-weight cells/ml. For oxygen consumption : main compartment contained $1.0 \mathrm{ml} .0 \cdot 1 \mathrm{M}$ phosphate buffer ( $\mathrm{pH} 7 \cdot 0$ ) and $1.0 \mathrm{ml}$. cell suspension; $0.5 \mathrm{ml}$. $0.01 \mathrm{M} 3$-methylfructose (or water in controls) in side bulb, and $0.2 \mathrm{ml} .10 \% \mathrm{NaOH}$ with filter-papers in inner cup. For $\mathrm{CO}_{2}$ production, conditions as above and in addition $0.5 \mathrm{ml}$. $2 \mathrm{~N}-\mathrm{H}_{2} \mathrm{SO}_{4}$ in side bulb 2 but without $\mathrm{NaOH}$ in inner cup; air.

For fermentation experiments : main compartment $1.0 \mathrm{ml}$. washed suspension $+1.0 \mathrm{ml}$. $0.03 \mathrm{M}-\mathrm{NaHCO}_{3} ; 0.5 \mathrm{ml}$. 0.01 M 3-methylfructose in side bulb 1 , and $0.5 \mathrm{ml} .2 \mathrm{~N}-\mathrm{H}_{2} \mathrm{SO}_{4}$ in side bulb $2 ; 95 \% \mathrm{~N}_{2}+5 \% \mathrm{CO}_{2}$; all values in $\mu \mathrm{l}$.)

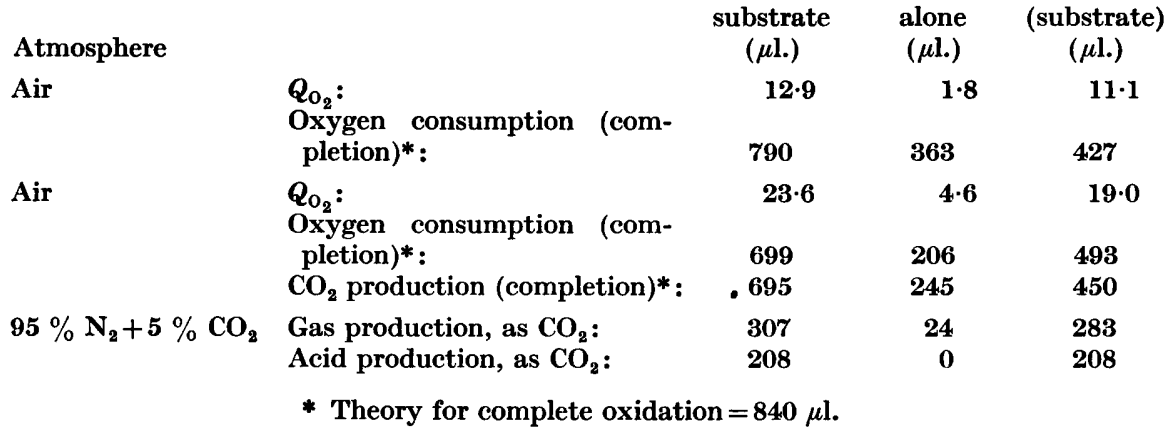


Table 1(b). Metabolism of 3-methylglucose by washed suspensions of cells grown in presence of 3-methylglucose

(Conditions similar to Table $1(a)$ with 3-methylglucose substituted for 3-methylfructose.)

Atmosphere

$$
\text { Air }
$$

Nitrogen

$95 \% \mathrm{~N}_{2}+5 \% \mathrm{CO}_{2}$

$$
\begin{aligned}
& Q_{\mathrm{O}_{2}}: \\
& \text { Oxygen consumption* } \\
& 150 \text { min.: } \\
& \text { Completion, } 12 \mathrm{hr} .:
\end{aligned}
$$

Hydrogen production: $\mathrm{CO}_{2}$ production: $\boldsymbol{Q}_{\mathrm{H}_{2}}$ :

$$
\begin{aligned}
& \text { Cells }+ \\
& \text { substrate }
\end{aligned}
$$$$
\text { ( } \mu \mathrm{l} .)
$$

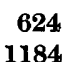

1184

Gas production, as $\mathrm{CO}_{2}$ :

Acid production, as $\mathrm{CO}_{2}$ :$$
24 \cdot 5
$$

227

233

7

\section{Cells \\ alone}

( $\mu$ l.)

Difference

(substrate)

( $\mu \mathrm{l}$.

$\begin{array}{ll}8 \cdot 7 & 15 \cdot 8\end{array}$

$299 \quad 325$

$728 \quad 456$

$17 \quad 210$

$31 \quad 202$

0 7

$16 \quad 383$

$\begin{array}{lll}159 & 0 & 159\end{array}$

* Theory for complete oxidation $=840 \mu \mathrm{l}$.

continued until the rate of oxygen consumption in presence of the given methyl-sugar had fallen to the rate in manometers without substrate. Table 1 , $a$ and $b$, shows that for both methyl-sugars the oxidation continued until the oxygen uptake (allowing for blank respiration) had reached a value approximately $55 \%$ of that required theoretically for complete oxidation of substrate. The $\mathrm{CO}_{2}$ output was approximately equal to the oxygen consumption. When washed suspensions were incubated anaerobically in $\mathrm{N}_{2}$ or $\mathrm{N}_{2}+\mathrm{CO}_{2}$ atmospheres, evolution of gas took place. With 3-methylglucose in $\mathrm{N}_{2}$, the gas evolved consisted of approximately equal volumes of hydrogen and carbon dioxide. Experiments in bicarbonate buffer indicated (Table $1 a$ and $b$ ) that, under anaerobic conditions, acid was also produced. Allowing for the fact that the gas produced contained hydrogen, the acid formed was approximately equivalent to the $\mathrm{CO}_{2}$ formed during the fermentation.

\section{Effect of presence of substrate during growth}

The organism was grown in basal medium with 3-methylfructose, 3-methylglucose or glucose as sole carbon source. Washed suspensions were prepared and the ability to oxidize the methyl-sugars tested. Table 2 shows that neither

\section{Table 2. Effect of growth substrate on ability to oxidize 3-methylglucose}

\begin{tabular}{|c|c|c|}
\hline $\begin{array}{l}\text { Glucose } \\
Q_{\mathrm{O}_{2}}(\mu 1 .)\end{array}$ & $\begin{array}{c}\text { 3-Methylglucose } \\
Q_{\mathrm{O}_{2}}(\mu 1 .)\end{array}$ & $\begin{array}{c}\text { 3-Methylfructose } \\
\mathbf{Q}_{\mathrm{O}_{\mathbf{2}}}(\mu \mathrm{l} .)\end{array}$ \\
\hline $32.5(0.5)$ & $1.0 \quad(0.5)$ & $0.0(0.5)$ \\
\hline - & $73.6 \quad(9.5)$ & $65.8(9.5)$ \\
\hline- & $69 \cdot 2(13 \cdot 2)$ & $64.5(13.2)$ \\
\hline
\end{tabular}
and 3-methylfructose

(Conditions similar to those given in Table $1(a)$. Rate of oxygen uptake studied over $1 \mathrm{hr}$. and expressed as $Q_{\mathrm{O}_{2}}=\mu \mathrm{l}$. oxygen taken $u p / \mathrm{hr} . / \mathrm{mg}$. dry-weight cells. Figures in ( ) are those for endogenous respiration blanks.)

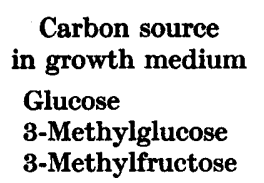

Carbon source
in growth medium
Glucose
3-Methylglucose
3-Methylfructose 
3-methylfructose nor 3-methylglucose was attacked by cells grown in glucose but that both methyl-sugars were attacked by cells grown in the presence of either. It appears probable that the primary breakdown of the methyl-sugars requires the presence of an adaptive enzyme evoked by the presence of either 3-methylglucose or 3-methylfructose.

The authors are indebted to Prof. F. G. Young, F. R. S., for suggesting this research and for the supply of 3-methylglucose and 3-methylfructose (from Messrs Ayerst, McKenna and Harrison Ltd., Montreal) and to Dr E. F. Gale for his valuable help throughout this investigation.

\section{REFERENCES}

Bardsley, D. A. (1934). The distribution and sanitary significance of B. coli, $B$. lactis aerogenes, and intermediate types of coliform bacilli in water, soil, faeces and ice-cream. J. Hyg., Camb., 34, 38.

Bergey's Manual of Determinative Bacteriology (1948), 6th ed. Ed. Breed, R. S., Murray, E. G. D. \& Hitchens, A. P. London: Baillière, Tindall and Cox.

Campbell, P. N. (1949). Metabolic studies with 3-methylglucose. Biochem. J. 44, lii.

Stephenson, M. (1949). Bacterial Metabolism, 3rd ed. London: Longmans, Green and $\mathrm{Co}$.

Wilson, G. S., Twigg, R. S., Wright, R. C., Hendry, C. B., Cowell, M. P. \& MaIER, I. (1935). Spec. Rep. Ser. med. Res. Coun. no. 206. London: H.M.S.O.

(Received 22 February 1951) 